\title{
The Role of Rulers in the Winding Up of the Old Norse Religion
}

\author{
Olof Sundqvist \\ Department of Ethnology, History of Religions and Gender Studies, \\ Stockholm University, Sweden \\ olof.sundqvist@rel.su.se
}

\begin{abstract}
It is a common opinion in research that the Scandinavians changed religion during the second half of the Viking Age, that is, ca. 950-1050/1100 CE. During this period, Christianity replaced the Old Norse religion. When describing this transition in recent studies, the concept "Christianization" is often applied. To a large extent this historiography focuses on the outcome of the encounter, namely the description of early Medieval Christianity and the new Christian society. The purpose and aims of the present study are to concentrate more exclusively on the Old Norse religion during this period of change and to analyze the questions of how and why it disappeared. A special focus is placed on the native kings. These kings played a most active role in winding up the indigenous tradition that previously formed their lives. It seems as if they used some deliberate methods during this process. When designing their strategies they focused on the religious leadership as well as the ritual system. These seem to have been the aspects of the indigenous religion of which they had direct control, and at the same time, were central for the modus operandi of the old religion. Most of all, it seems as if these Christian kings were pragmatists. Since they could not affect the traditional worldview and prevent people from telling the mythical narratives about the old gods, they turned to such aims that they were able to achieve.
\end{abstract}

\section{Keywords}

religious change - demise - active dismantling - Old Norse religion - Viking Age rulers - strategies and tactics - pragmatics 
It is a common opinion in research that the Scandinavians changed religion during the second half of the Viking Age, that is, ca. 950-1050/1100 CE. During this period, the Old Norse religion was replaced by Christianity. The change of religion was not an incident that took place overnight. Rather it should be described as a long and complicated process, including several phases of adjustments, adaptations, and changes (e.g., Birkeli 1973; Gräslund 20o1; Brink 2008). The disintegration of the indigenous religion further took place at different times in different places in Scandinavia (Gräslund 2001; Nordeide 2011; Ljung 2016). The first areas to change religion were probably in Denmark. King Harald Klak was baptized as early as 826 in Mainz, however, usually the official conversion in Denmark is related to King Harald Bluetooth Gormsson's baptism in 963. Norway and Iceland changed religion more officially around the year 1000, while the famous sanctuary of the Swedes in Old Uppsala was mentioned as still existing in Adam of Bremen's account dated to ca. 1075 (see Schmeidler 1917: 257-263); apparently, it ceased operation shortly thereafter. Rulers and the social elite changed religion early in this process and often before the wider population layers (cf., e.g., Sanmark 2004; Berend 2007a; Brink 2008; Nordeide 2011; Winroth 2012). This type of conversion is often described as a top-down process.

When describing this transition in recent studies, the concept of "Christianization" is often applied (see, e.g., Nilsson 1996; Sigurðsson 2003; Sanmark 2004; Berend 2007b; Nordeide 2011; Antonsson 2014). ${ }^{1}$ These studies discuss transformations of religious beliefs and rituals, the introduction and adoption of Christianity, the emergence of a different type of royal institutions and organizations, and new economic and social structures. Due to these processes, it is argued that the Scandinavian kingdoms became "integrated into the wider cultural and political community of western Christianity" (Lindkvist 2008: 669). To a large extent this historiography focuses on the outcome of the encounter, namely the description of early Medieval Christianity and the new Christian society. The concept of Christianization highlights the success and "victory"

1 According to Berend, the concept of Christianization refers to "the process of the penetration of Christianity into society and accompanying societal change" (2007a: 2). Nordeide states that the term covers "religious transformations but also social, cultural, and even technological developments" (2011:3), while Russell argues that the term "societal Christianization" denotes "the transformation of the beliefs, attitudes, values, and behavior (вАVв) of the society" (1994: 31). According to Antonsson, Christianization denotes "the process through which behaviour and beliefs were moulded according to the precepts of the Christian community and the Church" (2014: 51). 
of the winning part in this encounter. The purpose and aims of the present study are to concentrate more exclusively on the Old Norse religion during this period of change and to analyze the processes behind its disappearance. While some previous studies also mention such aspects, few of them are interested specifically in the vanishing religion. ${ }^{2}$ To generalize, there is actually a lack of knowledge in religious studies with regard to investigating how and why religious "traditions, practices, or indeed entire systems disappear" (de Jong 2016: 647). This article intends to bring findings from the field of Old Norse religion into this nascent conversation, focusing especially on the role of Viking kings in the winding up of the indigenous religion. ${ }^{3}$

The theoretical perspective is mainly inspired by Joel Robbins's study (2014) on the Urapmin in Papua New Guinea, where he pays attention to the ways people actively dismantle the religious tradition that previously shaped their lives. Robbins emphasizes that the disappearance and persistence of a religious tradition could be seen as "something people actively do, rather than something that simply happens" (2014: 13). This perspective could also be applied to the Viking kings in Scandinavia. They played an important role as supreme cult leaders, and people followed them in religious matters (Sundqvist 2002; 2016). It will be argued that these kings played a most active role when dismantling their own ancestral religion, replacing it with Christianity. This article will discuss some deliberate methods used by these kings in their endeavors. First the question of how they proceeded will be analyzed as well as the strategies and tactics they applied in their endeavors to remove the indigenous religion. To avoid problematic generalizations of previous research in this part, a historical and contextual approach will be used. The method in this part is thus mainly empirical and inductive. When discussing the why-question, theories and typologies of religion used by, for example, Gro Steinsland (1991, 2000, 2005) and Jens Peter Schjødt (2013) in similar contexts will be discussed. They claim that the missionaries identified certain areas where the old religion was vulnerable, which they later also attacked. As an alternative to their suggestions,

2 In the volume Christianization and the Rise of Christian Monarchy aspects of the declining religions are indeed taken into consideration. The editor Nora Berend expresses the hope that "further research may shed light on issues of pagan religion" (2007a: 10). Antonsson has in a recent review article noted some fundamental factors, which need to be addressed in future research on the conversion and Christianization of Scandinavia, for instance, "the nature of pre-Christian customs prior to the official adoption of the new religion", and "the role of rulers in introducing or even imposing the new religion" (2014: 50).

3 The importance of the kings with support from local rulers in the "Christianization process" is often stressed in recent research, see, e.g.: Sanmark 2004: 34-39, 75-83; Berend 2007a: 13-15, 38; Brink 2008: 622 . 
or as a complement to them, it will be argued that it was pragmatics that were at stake when choosing strategies and tactics for winding up the old religion. Since the recently converted Christian kings could not change the worldview of the people, they did what was in their power to do, such as abandon their own traditional cultic roles, or persuade the local chieftains to give up their cult assignments. When their power position increased, they could also destroy the old sanctuaries and in a later phase prohibit traditional customs by means of laws.

\section{Previous Theories and Research: A Brief Survey}

Previous scholars have described the processes related to the demise of the Old Norse religion in different ways. Roughly speaking, three theories can be distinguished (however, there are no watertight bulkheads between them; sometimes they actually overlap with each other): (1) the theory of decay, (2) the theory of clash, and (3) the theory of adaptation.

(1) Scholars applying "the theory of decay" (Norwegian forfallsteorin) argue that the old religion was in a process of "dissolution" during the Viking Age, due mostly to internal causes (e.g., Engelstad 1927; Gunnes 1976; Stæcker 1999: 243-244). There was a "crisis in belief system," since the Scandinavians themselves perceived the old religion as archaic and even ridiculous. It had outlived itself. The internal crisis led to a "religious vacuity," which opened the way for Christianity. The shift of religion was therefore a smooth, peaceful, and painless process. A serious problem with this theory is that it often implies a normative, evolutionistic, and biased attitude against the old religion when describing it as "primitive," "archaic," and "dying" (Steinsland 1991: 335-338; 2000: 82-84).

(2) Contrary to "the theory of decay," some scholars have argued that the old religion was strong, creative, and vibrant to the very end of its existence. However, it was perceived as a quite different type of religion compared to Christianity. Scholars have claimed that this meeting must have caused a dramatic clash (e.g., Steinsland 1991: 336-340; 2000: 28-31, 82-89; 2005: 434-444; cf. Bagge 2005: 81). Proceeding mainly from written evidence, they state that people were conscious that they lived in a time of profound and dramatic change, and in many cases the ending of the old religion was abrupt. ${ }^{4}$ By

4 Based mainly on archaeological finds in Norway, Sæbjørg Walaker Nordeide came to a similar conclusion: "Non-Christian cult activity seems to have ended abruptly ... No gradual changes in Norse cult in favour of Christian cult have been perceived; rather, the opposite tendency has been observed" (2011: 321). 
means of external causes, such as constraint and force, people were made to give up their native beliefs, because of religious intolerance. The missionaries were supported by a new type of Christian royal power, which had social and political interests in changing religion. According to this model, conversion should be described as a fast top-down process. Gro Steinsland, a main supporter of this "theory of clash" draws on a general typology of religion, where the old religion and Christianity represent two opposite types of religion. One objection against Steinsland's "theory of clash" is that it relies too much on written sources and overlooks the information from archaeological sources (see, e.g., Gräslund 1996: 20). To a certain degree, Steinsland also disregards the possibility that Roman Christianity was already Germanized when it arrived in Scandinavia and that it had gone through a long process of acculturation, while passing Germanic areas in Europe from 400 to $800 \mathrm{CE}$. The Church and the Christian missionaries probably adjusted themselves to Germanic conditions upon entering Central and Western Europe in the 6th century. This process is often called "the Germanization of Christianity" or "the Christo-Germanic syncretism" (see Russell 1994; Winroth 2012: 128-137). ${ }^{5}$ The sharp contradictions between the old and the new religion can thus have been abraded when Christianity and the missionaries appeared in the Nordic countries around $800 \mathrm{CE}$. Another problem with Steinsland's theory is that she fails to take regional and contextual aspects into consideration. ${ }^{6}$ It is possible that conflicts occurred sometimes, at some places during the transition, but perhaps not always (see, e.g., Sanmark 2004; Berend 2007b). Many people saw the benefits of Christianity and therefore they were baptized voluntarily.

(3) "The theory of adaptation," including the ideas of syncretism and continuation, could be seen as a variant of the first theory, since it emphasizes a gradual, long, and conflict-free process, but it does not emphasize internal dissolution to the extent of the former theory. Instead, scholars state that the practitioners of the old religion were tolerant and had a great ability to adopt new religious elements. Scholars working with this theory have thus argued that Christian ideas and practices slowly seeped into and infiltrated the Old Norse religion (e.g., Hernæs 1995; Gräslund 2001; Brink 2008; Winroth 2012; Bønding 2020). These ideas and rites slowly rubbed on and exhausted the vitality of the old religion. Archeologist Anne-Sofie Gräslund (2001: 9-10, 29-64), for instance, argues that the burial customs in Sweden indicate that Christian

5 Even if Steinsland (2000: 89-92) is aware of this process, she does not factor in that it has consequences for her conflict theory. She argues that the Germanization of Christianity mainly had an impact on the formation of rulership.

6 Steinsland is much more nuanced in more recent publications, see, e.g., Steinsland 2005: 421-454. 
burial practice slowly infiltrated and pushed away the old customs. Gräslund also presents evidence of syncretism in Sweden. She refers, for example, to a Viking Age amulet made of silver from Lugnås, which on the one side has a Thor's hammer depicted, and on the other side a Christian cross. Gräslund describes the process of changing religion as a top-down process, where the Scandinavian rulers first converted, since they were affected by the conditions in continental Europe where Church and worldly power were united. Magnates and rich farmers in their homelands converted later as an act of loyalty to the rulers and perhaps since this also brought benefits to them (2001: 144). In this context, Gräslund also adopts the model of Fridtjov Birkeli (1973), which was applied to the Christianization of Norway. According to him, Christianization was a long process, which can be divided into three phases: a phase of infiltration, a phase of mission and a phase of organization. Although some objections can be raised against the use of this model, it could, according to Gräslund, also be applied to certain areas in Sweden and Denmark (2001: 19-20). It has also been argued that the rupture was not total when Christianity was established in the 12th and 13th centuries. The sources indicate, for instance, a strong continuity of the old beliefs and practices during this period, including several religious acculturation processes, where native Norse and Christian elements were mingled, especially in popular beliefs, but actually also in the official Christian religion (Hultgård 1992; Bønding 2020).

Recent historiographic accounts of the transitions often use Christianization as an analytic concept. These studies often focus on the outcome of the religious and cultural encounter, that is, the description of the early Christianity and the rise of Christian polities (see above). The intention of the present study is to concentrate on the old religion during the encounter. As mentioned above, the questions how and why it disintegrated will be discussed and especially a focus will be placed on the rulers in this process and their role in the winding up of the native tradition. When discussing these issues, it will be argued that a more contextual approach is needed, in order to avoid the problematic generalizations noticed in previous research. First, however, the question of why the Viking kings changed religion must be addressed. It seems that they chose to convert and accept European culture voluntarily.

\section{Why Did the Viking Kings Change Religion?}

The question of why Scandinavian rulers wanted to change religion has been addressed in previous research. What did they gain by converting? The standard answer is that the rulers aimed at building strong power at home and at avoiding external threats, especially by the conquest of the Frankish-Germanic 
Empire (Berend 2007a: 13-14). This motive has, for instance, been applied for Harald Bluetooth's conversion in Denmark 963. Most likely, he wanted to avoid a conflict with the Germans. If Denmark was under a Christian rule the Empire had lost their legitimate right to attack Denmark and start war against king Harald (e.g., Sanmark 2004: 81; cf. Gelting 2007: 80-87). Even if this answer can be applied in this context it is far from general. Sometimes kings converted because they were threatened internally from groups in their homelands. The Danish king Harald Klak (r. 826-827), for instance, who ruled over some areas in Denmark, was met with hate and enmity from kings in his own country. He asked for support from the Emperor, Louis the Pious, according to Vita Anskarii (Waitz 1884: 26-29). Louis demanded that Harald Klak convert and finally he was willing to be baptized together with his wife, his son, and warriors; this took place in Mainz 826. When he returned to Denmark with the missionaries Ansgar and Autbert, he was quickly overthrown.

Christianity brought different types of benefits for the newly converted kings, for example prestige, legitimacy, political advantages, new trade relations, and a possible raise of status. Olaf Tryggvason (r. 995-1000) and Olaf Haraldsson (r. 1015-1030) had as youngsters on their Viking journeys abroad watched and understood how to be and act as a Christian king. They had also recognized how important it could be to ally with the Church for ruling the kingdom, and that the document-based church administration was a most useful tool to rule an administration of a kingdom (Brink 2008: 623). By means of Christianity, the Scandinavian rulers also built up their social and religiopolitical networks in Europe. According to Adam of Bremen, King Olaf Eriksson of Sweden (r. 995-1022), let his daughter Ingegerd marry the saintly King Yaroslav of Russia, and he himself was married to a West-Slavic maiden called Estrid, from the tribe of the Abodrites (Schmeidler 1917: 99-100). He was also in contact with Archbishop Unwan of Bremen and together they established the see of Skara with Thurgot as bishop (Schmeidler 1917:118-119). When building up these social networks, exchanges of gifts were crucial. The Viking kings piled up gold, silks, and precious objects of all kinds in their hall buildings. Different kinds of exotic objects impressed visitors and were thus used when constructing power. Recently it has been argued that Christianity itself could be regarded as such an exotic gift in these gift-giving relationships (Brown 2013; Winroth 2012).

One important reason for converting was probably also the relative novelty of Christianity, especially for the young rulers who had been out on Viking voyages in Christian Europe. Olaf Tryggvason and Olaf Haraldsson had probably adopted Christian culture early and established networks in many places in Europe, where Christianity was well established. It was therefore socially 
difficult for them to maintain practicing traditional religion when returning to their homeland (cf. Robbins 2014: 6-7). They were probably convinced of the advantages of Christianity, its usefulness and, perhaps, also its possibility of expressing emotions (cf. de Jong 2016: 658). Christianity also brought a new form of ideological legitimacy for kingship, which actually was adapted to the ancient Germanic ruler ideology (see, e.g., Russell 1994; Steinsland 2000; Sundqvist 2002; Bønding 2020). This type of ideology was accepted not only in Scandinavia, but also in other parts of Northern Europe.

I will argue, in what follows, that the Viking kings played a most active role when dismantling the old religion and replacing it with the new religion. They used some deliberate methods in their endeavor to remove the indigenous religion. Four important areas seem to have been in focus in their efforts.

The Erasure of the King's Ritual Role and the Royal Rites in Sacrificial Cult

As noted in previous research, a very important aspect of religious life in Old Scandinavia was the sacrificial feasts and the cult activities related to them (e.g., Hultgård 1993; Dillmann 1997; Steinsland 2000; Sundqvist 2002, 2016). These rites were supposed to follow a strict liturgical order, where also the ruler must take part in certain moments, such as the ritual drinking ceremonies and the consumption of horsemeat at the community meals. The blood was considered as the gods' part at such feasts and the horse liver the king's part (Sundqvist 2017). Through these annual offerings, where the ruler's ritual performances were vital, the congregation expected a gift in return from the gods, such as good crops and peace. These expectations are indicated by the formula til árs ok friðar (for good crops and peace) recited at the sacrifices (Hultgård 2003). If the king did not take part in these ceremonies, and performed his "royal rites," the entire ritual was considered a failure. Several medieval sources indicate that the early Christian kings refused to play their part at these ritual feasts. According to scholion 140 in Adam of Bremen's Gesta, the Christian king of the Swedes, Anunder, refused to perform the prescribed sacrifice, probably at the chief sanctuary in Uppsala, sometimes during the mid-11th century. ${ }^{7}$ The Svear therefore deposed him from office. Parts of this text seem to be built on a topos related to the hagiographic literature with

7 See Schmeidler 1917: 259. For an evaluation of this text, see Sundqvist 2016: 110-132. 
Biblical references. On the other side, we cannot rule out that Adam also had some information about this Christian king. ${ }^{8}$ It is therefore possible to interpret Anunder's action as a deliberate tactic for disrupting traditional liturgical order in Uppsala. Snorri Sturluson reports in his Hákonar saga góda 14-18 (ca. 1230) (Adalbjarnarson 1979: 1:167-173) that the Christian king Hakon the Good of Norway refused to consume the sacrificial (horse) meat when visiting the pagan farmers at the cult sites of Lade and Mære, Trøndelag, during the mid-1oth century. This method turned out to be a tactical failure for him, since the farmers were strong enough to force the king to perform the old rituals. ${ }^{9}$ According to the U-version of Hervarar saga (ca.130o), the Svear removed their Christian king Ingi from office ca. 1080, since he would not make sacrifices on their behalf at the assembly, which probably was held at Uppsala. Instead, they chose another king, called Blotsvein (the brother of the queen) who retained sacrifices (Helgason 1924: 160). Some parts of this tradition are also preserved in older texts, such as Orkneyinga saga (ca. 1200) (Gudmundsson 1965: 90).10

These sources indicate that these kings' denials to perform traditional sacrifice were a hard blow for the practitioners and advocates of the old religion. In some cases, they were even dethroned by the congregation. Hence, their refusal could be interpreted as an intentional method, or tactic, for dismantling the old cult.

\subsection{The Erasure of Cult Leadership}

According to the sources, the newly converted rulers tried to win over the local chieftains and the magnates to their program of a new religion. In this way, the new royal power could also effectively eliminate the most important and driving actors in the old cult. As noted in previous research, the pre-Christian rulers and the local chieftains organized and led the public cult jointly at the sanctuaries, since a well-trained, professional and independent priesthood similar to

8 It should be noticed that this scholion 140 appears in the oldest manuscript of Adam's text, namely A2, which usually is dated to about 1100 (Hultgård 1997: 12-15). It was thus made only 25 years after Adam wrote his text on contemporary conditions in Uppsala.

9 This information appears also in some older prose texts: Ágrip, (Einarsson 1985: 8); Fagrskinna (Einarsson 1985: 80). For a source critical survey of these texts, see Sundqvist 2016: 132-147.

10 Snorri was also acquainted with this tradition about Blotsvein, see Aðalbjarnarson 1979: 3:263. Yet Blotsvein (in Old Swedish Blodhsven) is also mentioned independently of Icelandic traditions in "The Legend of St Eskil," see Fant 1818-76: 2, 1:391-399. Blotsvein's existence has been questioned by Lönnroth 1996: 150-151. But Sävborg (2017) and Charpentier Ljungkvist (2018) argue in support for his historicity. 
the Roman Catholic priesthood (sacerdotes) was lacking (Hultgård 1997: 19-20; Sundqvist 2016: 163-198). The religious institution that regulated religious discourse, practices, and community in Scandinavia was an integrated aspect of the general office of rulership. Sources indicate that the newly converted kings, and the missionaries working for them, seem to have concentrated their attention particularly on the local chieftains. This was probably a deliberate strategy since they constituted the core and engine in the indigenous cult. The sources report that in order to persuade them to give up their ancestral religion, the Christian rulers sent out missionary bishops and priests who preached the faith for them, but they also used several other strategies, such as negotiations and assembly decisions (see below), ${ }^{11}$ the giving of gifts, ${ }^{12}$ or even violence. According to some sources, chieftains who continued to organize and perform the old cult were to be killed by the ruler's retinue (see below). Those chieftains who accepted Christianity contributed in their turn to the dismantling of the indigenous religion on a local level by refusing to perform their traditional roles there; instead they erected churches. The support from these local actors was necessary for a "successful Christianization" (Berend 2007a: 38).

\subsection{The Material Erasure of Ancestral Cult}

It seems as if the rulers also employed strategies for the "material erasure" of the indigenous religion. Sources report that negotiation was used by the rulers when dismantling the cult buildings, and ritual paraphernalia. Óláfs saga Helga 111-112 (Heimskringla), for instance, reports that after an assembly, where the farmers from Lesjar, Lóar, and Vági met St. Olaf and his clergies, they all went home and dismantled their cult houses (ok brotit niðr blóthús sín) and accepted Christianity (Aðalbjarnarson 1979: 2:183-186). Sometimes also violence was used when destroying the sanctuaries and cult images (see below). A few sources even suggest that the newly converted kings desacralized burial monuments over their pagan ancestors and performed performative rituals in order to have their dead forefathers also "Christianized" and buried in consecrated ground. The archaeological finds and runic stones of Jelling, for example, indicate that the pagan king Gorm (d. 958) was "Christianized" by means

11 The method of using missionary priests and assembly decisions can be seen in Iceland: see Íslendingabók 7, (Benediktsson 1986: 14-18), as well as in Svetjud, Norway, and Denmark, e.g., Adam of Bremen (Schmeidler 1917: 118-119); Den celdre Gulathings-Lov, 10 (Keyser and Munch 1846: 7-8); Widukind (Waitz 1882: 80-81; Bachrach 2014: 139-140).

12 See, e.g., how the skald Sigvat Thordsson (ca. 995-1045) praises King Olaf Haraldsson for the gifts he has received in, e.g., Erfidrápa Óláfs helga 27 (Whaley 2012: 1:696). See also Sanmark 2004: 78 . 
of a translatio-ritual, where king Harald (r. 958-987) allowed the transfer of his father's remains from the pagan burial mound to the grave in the church (Roesdahl 2008; cf. Gelting 2007). These actions can be interpreted as deliberate methods for demounting the ancestral traditions.

\subsection{Legislative Measures and the Removal of Traditional Customs}

Medieval laws, which were formulated by royal power and Church jointly, report that also legislation was used as a strategy for erasing indigenous customs, such as the consumption of horsemeat, which was considered as sacrificial food (e.g., Sanmark 2004). The prescriptions stipulated in the Borgarthings-Lov are interesting, since they clearly indicate that eating horse, dog, or cat was regarded as pagan practice. The law states thus "when someone eats one of these [animals] without necessity then he has forfeited fortune and peace, land and property, and must leave for a heathen land and never return to where Christians are."13 The phrase "to leave for a heathen land" is significant. It also appears in the outlawry clauses regarding those who refused to baptize a child, neglected to pay tithe, or performed illegal marriages and divorces. All these practices were thus not in keeping with Christian customs (Sanmark 2004: 222-223). Also, the worship of the native gods at different types of sanctuaries was forbidden. Den celdre Gulathings-Lov mentions thus: "Heathen sacrifices are also banned for we are not permitted to worship any heathen god, or [any] mound, or [in any] heathen sanctuaries."14 The intention behind these regulations was probably to get rid of popular religious beliefs and customs, which still flourished in the 12th and 13th century.

It seems as if the methods applied by the rulers can be related to chronological developments, which also reflect the increasing power of the Christian kings. Those applied in (1) reflect a weak Christian king in an early phase of the religious change process, unable to compete with the pagan power in question. The strategies used in (2), (3), and especially (4) indicate a Christian ruler in a later phase, on the same level as the pagan power or even stronger.

13 En ef maðr etr ceinhuern pæenn lut nauðsynialaust, pa hcefir han firergort fe oc frið, lande oc lausum ceyri fare a land hceiðit oc kome aldri peer, sem kristnir men ero (Keyser and Munch 1846: 342).

14 Blot er oss oc kviðiat at vér scolom eigi blota heiðit guð. ne hauga. ne horga (Keyser and Munch 1846: 18). 


\section{A Contextual Approach Using All Types of Sources: Two Case Studies}

As noted above, there are mainly two competing theories in the research about the religious change in Scandinavia; one emphasizes that it took place under peaceful conditions, and the other accentuates conflicts and violent encounters. A problem with scholars applying these theories is that they tend to overgeneralize and fail to take regional and contextual aspects into consideration. The present investigation indicates that the newly converted rulers sometimes used militant methods in some contexts, but not in all situations. In many cases, they also used nonviolent means, such as the refusal to perform the "royal rites." Another problem related to the aforementioned theories is that they actually reflect two research fields, where scholars applying them use different methods and sources. Archaeologists, using archaeological materials, tend to emphasize that the religious change should be seen as a long, gradual, and peaceful process (e.g., Hernæs 1995; Gräslund 1996: 42-44; 2001: 127-128, 149; see, however, Nordeide 2011), while some historians (of religions), working with Old Norse texts, describe it as violent and abrupt (e.g., Steinsland 2000: 84; cf. Bagge 2005: 81). Hence, a more contextual approach is needed when discussing these strategies as well as the use of an interdisciplinary approach where various source types are applied. When investigating a particular case, the evidence in the written sources must thus be compared with the information found from archaeological excavations. In what follows, two well known, but illustrative, examples will be presented, showing that a contextual approach is necessary where also all types of sources are investigated and compared. ${ }^{15}$

\section{1 $\quad$ Violent Religious Change in Trøndelag}

Some texts referring to the transition period in Norway attest that newly converted kings sometimes used violence and the destruction of ceremonial buildings. The Kings' Sagas have plenty of references to how sanctuaries in late-1oth century Trøndelag were destroyed by king Olaf Tryggvason when he embarked on his mission work. According to these texts, the farmers in this region were very reluctant to give up their ancestral beliefs. In Óláfs saga Tryggvasonar 67-72, Snorri Sturluson describes the violent missions of the king at Mære in Trøndelag, where he killed the pagan chieftains and smashed their cult

15 Such contextual and interdisciplinary approach has recently been applied, see, e.g., the essays in Berend 2007b. See also the overview of regional and contextual studies in Antonsson 2014: 56-66. 
images (Aðalbjarnarson 1979: 1:317-318). Snorri's most important source for this passage was probably Saga Óláfs Tryggvasonar, written in Latin by the 12th-century monk Odd Snorrason. The Latin version is lost, but an Old Norse translation of it is preserved. This text is full of miracles and wonder tales, which are not present in Snorri's text (Steinsland 2000: 115). As in Snorri's version, however, Odd mentions that the pagan chieftains were killed beside the sanctuary, where King Olaf also insulted the pagan farmers by smashing their cult images (Halldórsson 2006: 279-280). According to a younger text called Óláfs saga Tryggvasonar en mesta, King Olaf had "the hof buildings burnt down and the horgr sanctuaries broken and had churches erected instead."16

These Sagas must be treated with caution when applied as historical sources. They were all written down almost 200 years after the actual events took place. Most of them are written in a kind of triumphalist manner and literary strategies have been used in order to create Christian heroes (Kristjánsson 1988: 157-160; Steinsland 2000: 113-129; Sanmark 2004: 82; Winroth 2012: 6-7, 115$118,151)$. In these sagas, heroic legendary materials about the kings merged with ecclesiastic traditions (Ólason 1998: 50). Since Olaf Tryggvasson is portrayed as a militant missionary also in the contemporary poems, we cannot dismiss their information completely (cf. Whaley 2012: 393). In Hallfrod Ottarsson's Óláfsdrápa, for instance, King Olaf is depicted as a violent opponent against paganism and a purger of heathendom: ${ }^{17}$

Thus I have learned this, that the shrine-destroyer piled up high corpseheaps in many a place; the raven often came to the blood of strife. The mighty ruler, fierce against heathen temples, formerly caused the kin of the Jamtr and Wends to fall in the mêlée; he became accustomed to that early.

WHALEY 2O12: $392^{18}$

16 ... let hann [King Olaf] brenna hof en briota horga ok rceisa j stadinn kirkjur ... Flateyjarbók I (Vigfusson and Unge 186o: 285) (ca. 1390).

17 This stanza is only preserved completely (1-8) in Fagrskinna (Einarsson 1985: 141-142). The second half $\left(5^{-8}\right)$ is also preserved in Snorri's Óláfs saga Tryggvasonar (Aðalbjarnarson 1979: 1:255). The contextual prose to this stanza indicates that the king harried in the areas around the Baltic Sea, such as the still pagan country Wendland. On Gotland he also met heathen people from Jämtland, according to Snorri. Whaley (2012: 389 and 393) argues that this context, which takes place before the king's conversion, is uncertain. Most likely the skald is portraying Olaf in his Christian role as militant missionary.

18 Svá frák hitt, at họva

hǫrgbrjótr í stað mǫrgum

(opt kom hrafn at heipta)

hlóð valkǫstu (blóði). 
Olaf is here described as "cruel against heathen temples" (végrimmr) and a "shrine-destroyer" (horgbrjótr). In order to perform his mission, the king must kill a lot of pagans. He piles up high corpse-heaps in many places, and the ravens come to the blood of strife - that is, the corpses - in order to eat them. One of Hallfrod's lausavísur (10) indicates that King Olaf used power and force when converting the Norwegians and Icelanders (Jónsson 1967-1973: B1: 159). It tells that the prince of the men of Sogn (Sygna reesir), King Olaf, had forbidden heathen sacrifices (at blót eru kviðjuð). Now people must set aside the ancient belief in destiny controlled by the Norns and abandon the worship of Odin's kin (láta allir ýtar Óðins aett fyr róða). Hallfrod, himself, is compelled to turn away from the descendants of Niord in order to pray to Christ (verðk ok neyddr frá Njarðar niðjum Krist at biðja) (Strömbäck 1975: 72). It is a bit complicated to estimate the historical source value of Hallfrod's poems on King Olaf, since they are all composed as praise poems. The expression that the king "piled up high corpse-heaps in many a place" is obviously an exaggeration and a way to flatter the king. If there had been no reality behind this expression, however, the audience would have perceived this statement as an insult, rather than flattery.

The medieval expressions formulated by Snorri and others can also be tested by comparisons with information from archaeological excavations. According to archaeologist Sæbjørg Walaker Nordeide (2011: 113, 123), the pre-Christian cult-building preceding the church at Mære in Trøndelag was destroyed by fire, probably started by Christians. Exactly when this took place is impossible to say. Regardless, the Christians placed their church on the ruins of the pagan cult building in a triumphalist manner. By such symbolic and performative actions, the missionary kings and their supporters probably hoped that the pagans would lose their old religion and instead turn to Christianity.

\subsection{Non-violent Transition in Iceland}

Different source types indicate thus that violence was used sometimes by Olaf Tryggvason when erasing the old religion. Other sources report that the same king applied other strategies in other contexts, for instance, when he was not in command of directly violent means. When King Olaf attempted to convert the people in Iceland, he concentrated his attention on the Icelandic chieftains. This was a deliberate method, since these leaders were those who organized

\footnotetext{
Endr lét Jamta kindir allvaldr í styr falla (vanðisk hann) ok Vinða végrimmr (á pat snimma).
} 
the old religion in Iceland, and also led public rituals; no well-trained and professional priesthood existed there. In order to reach all of them, he used the general assembly (Alpingi) at Dingvellir, where all the chieftains gathered every summer. Since he did not have access to this assembly himself, he used some Icelandic chieftains as his delegates. It is well known that Iceland lacked kings during the so called "Free State Period." It was ruled jointly by all chieftains called goðar (pl.). This title, goði (sg.), is a derivation of the Old Norse noun goð (n.pl.) meaning "gods," indicating that this denomination in some sense referred to a cult office (de Vries 1977:181). This assignment is also well-attested in many narrative sources.

Our main source for the processes related to religious change in Iceland is Ari Thorgilsson's Íslendingabók (ca. 1120-1132), which usually is considered as having a quite high historical source value. It has often been stated that Ari $(1067 / 68-1148)$ built his text on a strong oral tradition and that he frequently supported his information with references to his sources. Even if Íslendingabók sometimes has been regarded as a "myth of origins for the Icelanders" (Grønlie 2006: xxiv-xxx), some of Ari's information is usually regarded as accurate (cf. Kristjánsson 1988: 120-124; Ólason 1998: 44-45; Aðalsteinsson 1999: 55-57; Grønlie 2006: ix, xvi-xxii). ${ }^{19}$ Ari reports in chapter 7 that King Olaf sent to Iceland a priest called Thangbrand, who preached Christianity to people, and soon baptized three important chieftains, Hall Thorsteinsson, Hjalti Skeggjason, and Gizur Teitsson, but also many other chieftains. Those who spoke against Christianity and rejected it were still in the majority. After he had been there for a while, Thangbrand left. When he arrived in Norway and told the king everything that had happened and said that it was beyond expectation that Christianity might yet be accepted there, Olaf became very angry and stated that all Icelanders who were in Norway should be killed.

The king's method of using a priest for his mission in Iceland had obviously failed, but indirectly it would bear fruit in the longer run. The chieftains who Thangbrand converted came from wealthy and influential families (Strömbäck 1975: 25). Their families had in one or another sense, been involved in pagan public cult. Landnámabók reports that, for instance, Hall's grandfather Bodvar the White made his home at Hof in South Alftaford and that "he erected a great cultic building there" (hann reisti par hof mikit) (Benediktsson 1986: 310311). Also Gizur's grandfather Ketilbjorn had, according to Landnámabók a hofbuilding erected at Mosfell. He was so wealthy that "he told his sons to forge a

19 Other sources to this event are Theodoricus monachus' Historia de antiquitate regum Norwagiensium, Óláfs saga Tryggvasonar eptir Odd munk Snorrason, Kristni saga, Óláfs saga Tryggvasonar en mesta and Njáls saga. 
cross beam of silver for the temple they built, but they wouldn't do that." ${ }^{20}$ By baptizing Hall and Gizur, two important organizers of the indigenous religion in Iceland were removed from the scene, and at the same time, two influential advocates for Christianity were won over.

Ari reports further in Íslendingabók that Gizur and Hjalti went to a meeting with King Olaf. Due to the religious conditions in Iceland the king had decided to imprison all Icelanders in Norway. Gizur and Hjalti got the king to release them and promised him their help so that Christianity might yet be accepted in Iceland. Hence, these chieftains traveled back to their homeland with the mission to convert the Icelanders. They went to the Law-Rock at Alpingi and announced their mission there. The result was not a complete breakthrough at the pagan party, however. Ari reports that the pagan Lawspeaker Thorgeir Thorkelsson (Ljósvetningagoði) was asked by Hall to make the final decision regarding what kind of law would apply to Iceland, whether it should be a pagan or a Christian law, and they agreed upon that. Thorgeir withdrew to his shed, lay down, and covered himself with a cloak. He laid there all day and all that night, and he did not say a word. The next morning, he gathered the assembly at the Law-Rock and declared that the Icelanders should all have "one law and one faith" and added "if we tear law asunder, we tear asunder peace":

And he brought his speech to a close in such a way that both sides agreed that everyone should have the same law, the one he decided to proclaim. It was then proclaimed in the laws that all people should be Christian, and that those in this country who had not yet been baptised should receive baptism; but the old laws should stand as regards the exposure of children and the eating of horse-flesh. People had the right to sacrifice in secret, if they wished, but it would be punishable by the lesser outlawry if witnesses were produced. And a few years later, these heathen provisions were abolished, like the others.

GRøNLIE 2OO6: $9^{21}$

This text has been hotly debated, especially what Thorgeir actually did under the cloak (see especially Aðalsteinsson 1999). I will not go into it here. It is a fact,

$20 \quad$... at hann bauð sonum sínum at slá pvertré af silfri íhofit, pat er peir létu gera; peir vildu pat eigi ... (Benediktsson 1986: 385).

21 En hann lauk svá máli sínu, at hvárirtveggju játtu pví, at allir skyldi ein log hafa, pau sem hann réði upp at segja. Pá vas pat moelt í logum, at allir menn skyldi kristnir vesa ok skírn taka, peir es áđr váru óskírðir á landi hér; en of barnaútburð skyldu standa en fornu log ok of hrossakjgtsát. Skyldu menn blóta á laun, ef vildu, en varða fjorbaugsgarðr, ef váttum of kvcemi við. En sỉðarr fám vetrum vas sú heiðni af numin sem onnur (Benediktsson 1986:17). 
however, that the resolution proclaimed by Thorgeir led to a conversion among the chieftains, that is, exactly what King Olaf wanted. Ari also states explicitly that King Olaf was the one who brought Christianity to Iceland (Benediktsson 1986: 14). It is often argued that this was a pragmatic political event staged by the king, who also put pressure on the chieftains (cf. Ólason 1998: 32; Hugason 2000: 84-89; Karlsson 2000: 109; Stefánsson Hjaltalín 2012: 26-30). It seems nevertheless as if the decision made by Thorgeir had great legitimacy and was of most crucial significance. Indeed, Thorgeir wanted to dismantle the ancestral cult in a gentle way when he formulated the compromise concerning the right to follow the old law. But the consequence was a quite fast process of religious change. Archaeological sources indicate that heathen burial practices ceased quite abruptly after the assembly in the year 100o, and also the eating of horsemeat discontinued, although the Icelandic archaeological records do not allow us to state exactly when (Vésteinsson 20o1: 337; 2014: 78-79; cf. Antonsson 2014: 61-63).

If we can rely on the basic plot of Ari's account, we have first-class evidence of a situation where the king, by assistance of his delegates, intentionally focused on the pagan chieftains of Iceland in order to dismantle the indigenous religion there. In order to achieve this he used the assembly institution, where all chieftains were acquired to attend. All decisions made there were binding. The process there seems to have been a peaceful one; no contentions are reported. Sources state that some of the most important pagan chieftains also converted there, or soon after it. According to Kristni saga 12, Hjalti, on his way home from the assembly, baptized the old heathen goð $i$ Runolf Ulfsson (Grønlie 2006:50). Runolf was earlier one of the most prominent defenders of the old religion in Iceland. His transition was an important step for the extinction of the indigenous cult there. This saga reports that other important chieftains also converted after the decision. Snorri goði, for instance, came from one of the most famous goð $i$-families in Iceland, where all his forefathers had been pagan cult leaders. Snorri inherited his father's farm and the sanctuary at Helgafell. Eyrbyggja saga tells that he erected a church on his farm soon after the assembly decision 999/100o (Sveinsson and Pórðarson 1985: 136).

Sources show thus that the transition of these chieftains was done in a nonviolent way. When coming home, these local leaders actively dismantled their own sanctuaries in a respectful way. Archaeological excavations indicate that this actually happened. Some rituals were, for instance, performed at Hofstaðir, in Northern Iceland, when the great ceremonial hall was dismantled in the early ntth century. Several acts of closure were performed, such as the ritual depositions of the slaughtered and sacrificed skulls, which previously had decorated the old sanctuary. A new settlement was established in 
the south-western area of the leveled farm mound, where a church was built around 1000 (Vésteinsson 2014: 8o-81). This abandonment of the feasting hall should, according to the excavator Lucas Gavin (2009: 407-408), be related to the official conversion of Iceland. The archaeological finds there suggest that the transition process at Hofstaðir was negotiated and reconciled with preChristian practices without overt resistance.

It seems as if the strategies used by the native kings varied depending on the specific contexts. The sources related to King Olaf's mission in Trøndelag show that violent actions were sometimes applied. The king even killed the chieftains who organized the non-Christian cult. He also destroyed the old sanctuaries and the ritual paraphernalia by means of violence and fire, which sometimes led to a fast and abrupt transition of religion. Most likely, he had the power and resources to use such methods. In other contexts, however, the same king used other strategies. In the case of Iceland, he employed negotiations in order to have the pagan chieftains converted. The reasons why he used such means in this context are most likely due to the distance between Norway and Iceland and the fact that he had no power to use violence in this country. After winning over the Icelandic chieftains for Christianity, these leaders seem to have dismantled their own sanctuaries in a respectful manner. Changes in burial practice were quite rapid after the famous decision. Archaeological investigations show, however, that these changes had already started before Thorgeir gave his verdict, thus indicating a longer process. This is actually also attested by Old Norse literature.

Why Pagan Rituals and Religious Leadership?

This study has shown that the Christian rulers often focused on pagan rituals, religious leadership, and cult when dismantling the old religion in Scandinavia. Why did they do that? They could also have concentrated their attention on the traditional worldview and the belief system. The preserved mythic traditions in the Eddic and Skaldic poetry, as well as in the Snorra Edda, indicate that such ideas were well elaborated in the indigenous religion. Was there an inherent vulnerability of the traditional cult system, which the Christian rulers had identified and therefore attacked? In order to answer this question, some ideas developed by scholars who have used typologies of religion when investigating religious change in Scandinavia will be discussed. I will then present my own explanation.

Gro Steinsland (1991: 338-340; 2000: 85-89; 2005: 31-34, 2005: 434-444) states that the Old Norse religion and Christianity represent two different 
types of religion. The former religion can be classified as an "ethnic" and local "folk-religion," while the latter can be classified as a "universal, salvation religion." She presents a simple analytic model and typology:

Old Norse Religion
"Ethnic religion"
Turns to:
its own ethnic group
non-missionary
this-worldly
seeking peace in this world ( friðr)
oriented towards cult
exclusive regarding cult
tolerant regarding belief
non-dogmatic
tradition
polytheistic
male and female cult leaders
no cult buildings
Ethics:
honor and shame
collective

\section{Christianity}

"Universal religion"

all people on earth

missionary

other-worldly

seeking salvation and eternal life in the other world

oriented towards belief

tolerant regarding cult (?)

exclusive regarding belief

dogmatic

doctrine

monotheistic

male cult leaders

sacred buildings/churches

sin, grace, salvation and loss

individual

According to Steinsland, an important feature of the former type of religion is that it belongs to a certain group of people and that it merges with the culture of this group. If anyone belongs to this group, he or she is at the same time a part of the religious community. In comparison with this orientation toward "the collective," the universal religions are in principle "individual," because the religious belief is no longer part of the social community (see also Schjødt 2013: 309-310). According to Steinsland, this model also explains why Christianity ultimately stood as a victor when encountering the Old Norse religion. As with other "folk religions," the traditional religion in Scandinavia was vulnerable since it lacked a priestly organization supported by a strong institution in society, which in turn was held up by a power apparatus (Steinsland 2005:34).

Even if Steinsland's model in several senses is useful for understanding the encountering between religions of different types, several objections can be made. James L. Cox (2013), for instance, has stated that this type of typology often has been done rather uncritically. He points out several general problems with such classification: Being nonmissionary, for instance, "is not a characteristic exclusive to indigenous religion" (Cox 2013: 18). Some of 
the opposites Steinsland construes can also be questioned when applied to the transition in Viking Age Scandinavia (cf. Schjødt 2013: 309). One of them is her description of the Old Norse religion as characterized by its focus on tradition, customs, and cult activities, as something different to the Christian religion of the Middle Ages, which is distinguished by its individual, personal religiosity, with a focus on belief system. Traditions, customs, and rituals are crucial parts of most religions and cultures around the world, certainly including Medieval Christianity. The assumption that belief was more important in Medieval Christianity than cult activities, further, can also be questioned. It is a well-known fact that Roman Christianity emphasized religious practice and custom (e.g., Pernler 1999: 82-84). It should be mentioned, however, that Steinsland was aware that the historical reality was not as simple as the static model described above. The model represents an ideal situation, which can be discussed in all details.

The historian of religions Jens Peter Schjødt (2013), has developed Steinsland's phenomenological ideas further by following Jan Assmann's (2006) memory studies and the taxonomic division between primary and secondary religions, where the former religions can be distinguished from the latter ones on the basis of the fact that they do not include canonical writing. Schjødt argues that the Old Norse religion, which was based on a diversity of oral traditions and lacked canonical writings, can definitely be classified as a primary religion. He argues, further, that cultures without writings, such as the Scandinavian one, remember their religion through their rituals, and the continuous performance of them. When performing rituals, the "grand narratives" are brought into play. Some of them deal with creation or the end of the world, others with the relationship between the gods and the humans, and the role of gods in human life. When writing appears, these traditions are remembered without ritual performances. It was thus no coincidence when the Christian missionaries formulated their methods, Schjødt argues, that they aimed on forbidding the performance of pagan rituals (2013: 317). ${ }^{22}$ Also Schjødt's model could be discussed. It is true in theory that traditions are remembered without ritual performances when writing appears. In reality, most Christians remember the rituals and myths related to Christmas, for instance, because they have

22 Schjødt is aware of the paradox that we actually still have many mythic traditions preserved, which all tell us about pre-Christian world view. He states: "it is important to understand that the narratives that have survived up until present time should be seen, first and foremost, as expressions of either the need for entertainment or an antiquarian interest which was already becoming apparent in the Middle Ages, in the work of people like Snorri Sturluson and the anonymous compiler(s) of the Eddic poems" (Schjødt 2013: 317). 
listened to these narratives and performed these rituals during Christmas Mass, not because they have read the Gospels.

By means of these phenomenological analyzes, Steinsland and Schjødt identify some vulnerable areas of folk religions, respectively primary religions (such as the Old Norse religion), when encountered with universal religions, respectively secondary religions (such as Christianity). It seems as if these weaknesses of the folk religions / primary religions in such situations are related to two aspects:

(1) The lack of an independent priestly institution or authority, which regulated religious discourse, practices, and community.

(2) The lack of canonical or religious writings, which support the memory and persistence of the tradition.

Present empirical investigation, which has a more inductive approach, indicates that the new Christian rulers and their missionaries identified similar areas of vulnerability in the Old Norse religion when replacing it with the new faith. When designing their strategies, they focused on the weak religious leadership as well as the ritual system, which seems to have been very important for the persistence of the indigenous religion.

The most important reason why the rulers focused on these matters is, however, related to pragmatics. The recently converted kings did what was in their power to do. While it was not in their power to change the worldview and thoughts of people, they could abandon their own traditional roles in sacrificial cult, and in that way disrupt the old ceremonial order. As time passed and their political position became more stable and powerful, they could also persuade, or even force the local chieftains, who organized the old cultic activities at the sanctuaries, to abandon their roles. They could even kill those who were reluctant to desert these assignments, in order to support Christianity. In some contexts, they destroyed the old cult sites and the ritual paraphernalia. By means of such strategies they dismantled the indigenous religion on a local level. Finally, during the High Middle Ages, when the Christians rulers together with representatives from the Church had an even stronger position of power and support through an efficient administration, they prohibited traditional customs by means of law. These methods had consequences on a regional, or even an inter-regional level.

In sum, the recently converted Viking kings played a most active role when winding up the indigenous tradition that previously formed their lives. It seems as if they used some deliberate methods in this project and that they worked 
on some important areas of the old religion more than on others. When designing their strategies, they focused on the religious leadership as well as the ritual system, which seem to have been the aspects of the indigenous religion that were more under their control and at the same time central for the modus operandi of the pre-Christian religion. Most of all, it seems as if these Christian kings were pragmatists. Since they could not affect the traditional worldview and prevent people from telling the mythical narratives about the old gods, Odin, Thor, Frey, and Freyja, they turned to such aims that they were able to achieve. It was easier to control what people did than what they thought. Due to the specific contexts, these rulers used violent means sometimes, but usually nonviolent strategies or tactics were applied. Olof Tryggvason, for instance, used violence in Norway when dismantling the old religion, since he had the power to do that in such contexts. When removing the Old Norse religion in Iceland, the same king applied negotiations, since this island was so remote from Norway that a military operation was impossible to carry out. In a later phase, the medieval kings also used legislation in their quest to eradicate the old religion. The result of this study indicates that a contextual approach is needed in this context, and that an interdisciplinary method must be used, where various source types are applied.

\section{References}

Aðalbjarnarson, Bjarni. (ed.). 1979. Heimskringla I-III. (Íslenzk fornrit 26-28). Reykjavík: Hið íslenzka fornritafélag.

Aðalsteinsson, Jón Hnefill. 1999. Under the Cloak: A Pagan Ritual Turning Point in the Conversion of Iceland. Reykjavík: Háskólaútgáfan Félagsvísindastofnun.

Antonsson, Haki. 2014. "The Conversion and Christianization of Scandinavia: A Critical Review of Recent Scholarly Writings." In Ildar Garipzanov with Rosalind Bonté (eds.), Conversion and Identity in the Viking Age, Turnhout: Brepols, 49-73.

Assmann, Jan. 20o6. Religion and Cultural Memory: Ten Studies. Stanford, CA: Stanford University Press.

Bachrach, David A. (ed.). 2014. Widukind of Corvey. Deeds of the Saxons. Washington, DC: The Catholic University of America Press.

Bagge, Sverre. 2005. Mennesket i middelalderens Norge. Tanker, tro og holdninger 10oo1300. Oslo: Aschehoug.

Benediktsson, Jakob. (ed.). 1986. Íslendingabók. Landnámabók. (Íslenzk fornrit 1). Reykjavík: Hið íslenzka fornritafélag.

Berend, Nora. 2007a. "Introduction." In Nora Berend (ed.), Christianization and the Rise of Christian Monarchy: Scandinavia, Central Europe and Rus'c. 900-1200, Cambridge: Cambridge University Press, $1-46$. 
Berend, Nora (ed.). 2007b. Christianization and the Rise of Christian Monarchy: Scandinavia, Central Europe and Rus' c. 900-1200. Cambridge: Cambridge University Press.

Birkeli, Fridtjov. 1973. Norske steinkors i tidlig middelalder: Et bidrag til belysning av overgangen fra norrøn religion til kristendom. Oslo: Universitetsforlaget.

Bønding, Sophie. 2020. "Visions of Unity: A Comparative Study of the Role of PreChristian Nordic Religion in the Formation of Denmark as a Community, the 1oth and the 19th Centuries." Ph.D. diss., Aarhus University.

Brink, Stefan. 2008. "Christianisation and the Emergence of the Early Church in Scandinavia." In Stefan Brink in collaboration with Neil Price (eds.), The Viking World, London: Routledge, 621-628.

Brown, Peter. 2013. The Rise of Western Christendom: Triumph and Diversity, A.D. 2001000. Oxford: Wiley-Blackwell.

Charpentier Ljungqvist, Fredrik. 2018. "Hedniskt motstånd i Svealand under sent 100o-tal." Historisk tidskrift 138(2): 197-226.

Cox, James L. 2013. "Reflecting Critically on the Academic Study of Indigenous Religions." In James L. Cox (ed.), Critical Reflections on Indigenous Religions, London: Routledge, 14-27.

Dillmann, François-Xavier. 1997. "Kring de rituella gästabuden i fornskandinavisk religion." In Anders Hultgård (ed.), Uppsalakulten och Adam av Bremen, Nora: Nya Doxa, 51-73.

Einarsson, Bjrani. (ed.). 1985. Ágrip af Nóregskonunga sogum. Fagrskinna - Nóregs konunga tal. (Íslenzk fornrit 29). Reykjavík: Hið íslenzka fornritafélag.

Engelstad, Eivind S. 1927. "Hedenskap og kristendom 1. Sen vikingetid i innlandsbygdene i Norge." Bergens Museums Årsbok 1927. Bergen: Bergens Museum.

Fant, Ericus Michael. (ed.). 1818-1876. Scriptores rerum Suecicarum medii aevi. I-III. Upsaliae: Zeipel et Palmblad. Reg. Acad. Typographi.

Gelting, Michael. 2007. "The Kingdom of Denmark." In Nora Berend (ed.), Christianization and the Rise of Christian Monarchy: Scandinavia, Central Europe and Rus' c. 900-1200, Cambridge: Cambridge University Press, 73-120.

Gräslund, Anne-Sofie. 1996. "Arkeologin och kristnandet." In Bertil Nilsson (ed.), Kristnandet i Sverige: Gamla källor och nya perspektiv. (Projektet Sveriges Kristnande. Publikationer. 5). Uppsala: Lunne böcker, 19-44.

Gräslund, Anne-Sofie. 2001. Ideologi och mentalitet: Om religionsskiftet i Skandinavien från en arkeologisk horisont. (OPIA. 29). Department of Archaeology, Uppsala University.

Grønlie, Siân. (trans.). 20o6. Íslendingabók/Kristni saga. The Book of the Icelanders/The Story of the Conversion. (Viking Society of Northern Research). London: University of London. 
Guðmundsson, Finnbogi. (ed.). 1965. Orkneyinga saga: Legenda de sancto Magno. Magnúss saga skemmri. Magnúss saga lengri. Helga páttr ok Úlfs. (Íslenzk fornrit 34). Reykjavík: Hið íslenzka fornritafélag.

Gunnes, Erik. 1976. Rikssamling og kristning. 80o-1177. Knut Mykland (ed.). (Norges historie 2). Oslo: Cappelen.

Halldórsson, Ólafur. (ed.). 20o6. Óláfs saga Tryggvasonar eptir Odd munk Snorrason. In Fcereyinga saga. Óláfs saga Tryggvasonar eptir Odd munk Snorrason. (Íslenzk fornrit 25). Reykjavík: Hið íslenzka fornritafélag.

Helgason, Jón. (ed.). 1924. Heiðreks saga: Hervarar saga ok Heiðreks konungs. Copenhagen: Samfund til udgivelse af gammel nordisk litteratur.

Hernæs, Per. 1995. “Kristen innflytelse i Rogalands vikingtid." In Emil Lidén (ed.), Møtet mellom hedendom och kristendom i Norge. Oslo: Universitetsforlaget As, 80-120.

Hugason, Hjalti. 200o. Frumkristni og upphaf kirkju. Kristni á Íslandi, 1, Reykjavík: Alpingi. Hultgård, Anders. 1992. "Religiös förändring, kontinuitet och ackulturation/synkretism i vikingatidens och medeltidens skandinaviska religion." In Bertil Nilsson (ed.), Kontinuitet $i$ kult och tro från vikingatid till medeltid. (Projektet Sveriges Kristnande. Publikationer. 1). Uppsala: Lunne böcker, 49-103.

Hultgård, Anders. 1993. "Altskandinavische Opferrituale und das Problem der Quellen." In Tore Ahlbäck (ed.), The Problem of Ritual, (Scripta Instituti Donneriani Aboensis. XV), Stockholm: Almqvist \& Wiksell, 221-259.

Hultgård, Anders. 1997. "Från ögonvittnesskildring till retorik: Adam av Bremens notiser om Uppsalakulten i religionshistorisk belysning." In Anders Hultgård (ed.), Uppsalakulten och Adam av Bremen, Nora: Nya Doxa, 9-50.

Hultgård, Anders. 2003. "Ár-'Gutes Jahr unt Ernteglück' - ein Motivkomplex in der altnordischen Literatur und sein religionsgeschichtlicher Hintergrunt." In Wilhelm Hiezmann and Astrid van Nahl (eds.), Runica - Germanica-Mediaevalia, (Ergänzungsbände zum Reallexikon der Germanischen Altertumskunde. Band 37), Berlin: de Gruyter, 282-308.

Jong, Albert de. 2016. "The Disintegration and Death of Religions." In Michael Stausberg and Steven Engler (eds.), The Oxford Handbook of the Study of Religion, Oxford: Oxford University Press, 646-664.

Jónsson, Finnur. (ed.). (1912-1915) 1967-1973. Den Norsk-Islandske Skjaldedigtning 80o1400. AI-II, BI-II. Copenhagen: Rosenkilde och Bagger.

Karlsson, Gunnar. 2000. Iceland's 1100 Years: History of a Marginal Society. London: C. Hurst.

Keyser, Rudolf and P. A. Munch. (eds.). 1846-1849. Norges Gamle Love indtil 1387. Vols. I-III. Christiania: Chr. Grøndahl.

Kristjánsson, Jónas. 1988. Eddas and Sagas: Iceland's Medieval Literature. P. Foote (trans.). Reykjavík: Hið íslenzka fornritafélag. 
Lindkvist, Thomas. 2008. "The Emergence of Sweden." In Stefan Brink in collaboration with Neil Price (eds.), The Viking World, London: Routledge, 668-674.

Ljung, Cecilia. 2016. Under runristad häll. Tidigkristna gravmonument i 100o-talets Sverige. / Katalog över tidigkristna gravmonument. (Stockholm Studies in Archaeology 67:1-2). Stockholm University.

Lönnroth, Lars. 1996. "En färran spegel: Västnordiska berättande källor om svensk hedendom och om kristningsprocessen på svenskt område." In Bertil Nilsson (ed.), Kristnandet i Sverige: Gamla källor och nya perspektiv, (Projektet Sveriges kristnande. Publikationer. 5), Uppsala: Lunne Böcker, 141-158.

Lucas, Gavin. 2009. Hofstaðir: Excavations of a Viking Age Feasting Hall in North-Eastern Iceland. (Institute of Archaeology Monograph Series 1). Reykjavík: Fornleifastofnun Íslands.

Nilsson, Bertil (ed.). 1996. Kristnandet $i$ Sverige: Gamla källor och nya perspektiv. (Projektet Sveriges Kristnande. Publikationer. 5). Uppsala: Lunne böcker.

Nordeide, Sæbjørg. 2011. The Viking Age as a Period of Religious Transformation: The Christianization of Norway from AD 560-1150/1200. Turnhout: Brepols.

Ólason, Vésteinn. 1998. Dialogues with the Viking Age: Narration and Representation in the Sagas of the Icelanders. Reykjavík: Heimskringla.

Pernler, Sven-Erik. 1999. Sveriges kyrkohistoria: Hög- och senmedeltid. Stockholm: Verbum.

Robbins, Joel. 2014. "Theorizing Religious Traditions from the Point of View of How They Disappear." Cambridge Journal of Anthropology 32(2):2-15.

Roesdahl, Else. 2008. "The Emergence of Denmark and the Reign of Harald Bluetooth." In Stefan Brink in collaboration with Neil Price (eds.), The Viking World, London: Routledge, 652-664.

Russell,James C. 1994. The Germanization of EarlyMedieval Christianity:A Sociohistorical Approach to Religious Transformation. New York: Oxford University Press.

Sanmark, Alexandra. 2004. Power and Conversion: A Comparative Study of Christianization in Scandinavia. (OPIA. 34). Department of Archaeology, Uppsala University.

Sävborg, Daniel. 2017. “Blot-Sven: En källundersökning." Scripta Islandica 68: 51-97.

Schjødt, Jens Peter. 2013. "The Christianisation of the North - A New Kind of Religiousity." In Leszek Slupecki and Rudolf Simek (eds.), Conversions: Looking for Ideological Change in the Early Middle Age, Vienna: Fassbaender, 303-320.

Schmeidler, Bernhard. (ed.). 1917. Magistri Adam Bremensis Gesta Hammaburgensis Ecclesiae Pontificium. (Scriptores rerum germanicarum in usum scholarum. Ex Monumentis Germaniae Historicis. Editio Tertia). Hanover: Hahnsche Buchhandlung. Sigurðsson, Jón Viðar. 2003. Kristninga i Norden 750-1200. Oslo: Det norska samlaget. Staecker, Jörn. 1999. Rex regum et dominus dominorum. Die wikingerzeitlichen Kreuzund Kruzifixanhänger als Ausdruck der Mission in Altdänemark und Schweden, (Lund Studies in Medieval Archaeology. 23), Stockholm: Almqvist \& Wiksell. 
Stefánsson Hjaltalín, Torfi K. 2012. Íslensk kirkjusaga. Reykjavík: Flateyjarútgáfan.

Steinsland, Gro. 1991. "Religionsskiftet i Norden og Voluspá 65." In Gro Steinsland (ed.), Nordisk hedendom: Et symposium, Odense: Universitetsforlag, 335-348.

Steinsland, Gro. 2000. Den hellige kongen: Om religion og herskermakt fra vikingtid til middelalder. Oslo: Pax.

Steinsland, Gro. 2005. Norrøn religion: Myter, riter, samfunn. Oslo: Pax.

Strömbäck, Dag. 1975. The Conversion of Iceland: A Survey. P. Foote (trans.). (Viking Society for Northern Research. Text Series. Vol. 6). London: University of London.

Sundqvist, Olof. 2002. Freyr's Offspring: Rulers and Religion in Ancient Svea Society. (Historia Religionum. 21). Uppsala: Uppsala University.

Sundqvist, Olof. 2016. An Arena for Higher Powers: Ceremonial Buildings and Religious Strategies for Rulership in Late Iron Age Scandinavia. (Numen Book Series 150). Leiden: Brill.

Sundqvist, Olof. 2017. "Blod och blót: Blodets betydelse och funktion vid fornskandinaviska offerriter." Scripta Islandica 68: 275-308.

Sveinsson, Einar Ól., and Matthías Pórðarson.(eds.).1985. Eyrbyggja saga, Grœnlendinga sqgur: Brands páttr qrva. Eiríks saga rauða. Gronlendinga saga. Gronlendinga páttr. (Íslenzk fornrit 4). Reykjavík: Hið íslenzka fornritafélag.

Vésteinsson, Orri. 2001. “The Conversion of the Icelanders." In Przemysław Urbańczyk (ed.), Europe Around the Year 1000, Warsaw: Wydawn, 325-342.

Vésteinsson, Orri. 2014. "Shopping for Identities: Norse and Christian in the Viking-Age Atlantic." In Ildar Garipzanov with Rosalind Bonté (eds.), Conversion and Identity in the Viking Age, Turnhout: Brepols, 76-91.

Vigfusson, Guðbrandur, and C. R. Unge. (eds.). 186o-1868. Flateyjarbók: En samling af norske konge-sagaer med inskudte mindre fortcellinger. Christiania: P. T. Mallings.

Vries, Jan de. 1977. Altnordisches etymologisches Wörterbuch. Leiden: Brill.

Waitz, Georgius (ed.). 1882. Widukindi. Rerum Gestarum Saxonicarum. (Libri tres). Hanover: Hahnsche Buchhandlung.

Waitz, Georgius (ed.). 1884. Vita Anskarii. Auctore Rimberto. Accedit Vita Rimberti. Scriptores rerum germanicarum in usum scholarum. (Ex Monumentis Germaniae Historicis). Hanover: Hahnsche Buchhandlung.

Whaley, Diana. (ed.). 2012. Skaldic Poetry of the Scandinavian Middle Ages I. Poetry from the Kings'Sagas: From Mythical Time to c. 1035. Turnhout: Brepols.

Winroth, Anders. 2012. The Conversion of Scandinavia:Vikings, Merchants, and Missionaries in the Remaking of Northern Europe. New Haven, CT: Yale University Press. 